\title{
Securities Regulation for a Changing Market: Option Trader Standing Under Rule 10b-5
}

\author{
Elizabeth M. Sacksteder
}

Dominated until recently by stocks, bonds, and futures, America's capital markets now offer a dazzling array of new, derivative securities ${ }^{1}$ with option or option-like features. ${ }^{2}$ When the current scheme of federal securities regulation was originally devised, ${ }^{3}$ however, none of these exotic investment contracts was traded on the exchanges. ${ }^{4}$ The introduction of

1. As used in this Note, the term "derivative security" refers to a security that gives the holder a contractual claim on some underlying security.

2. See, e.g., H.R. REP. No. 626, 97th Cong., 2d Sess., pt. 1, at 2, reprinted in 1982 U.S. CodE Cong. \& AdMin. News 2780, 2780-81; J. Cox \& M. Rubinstein, Options Markets vii (1985); Amihud, Ho \& Schwartz, Overview of the Changing Securities Markets, in MARKET MAKING AND the Changing Structure of the Securities Industries 1, 4-5 (Y. Amihud, $T$. Ho \& $R$. Schwartz eds. 1985) [hereinafter MARKET MAKING]; Gilberg, Regulation of New Financial Instruments Under the Federal Securities and Commodities Laws, 39 VAND. L. REv. 1599, 1600 (1986).

An option is a contract giving the "holder" (buyer) of the option the right, but not the obligation, to buy from or sell to the "writer" (seller) of the option a specified number of securities at a particular price (the "exercise price" or "striking price") within a given period of time (the "exercise period"). In exchange for assuming the risk of having to buy or sell the underlying security at a disadvantageous price, the option writer charges the holder a price or "premium" for the option. See, e.g., $R$. Brealey \& S. Myers, Principles of Corporate Finance $429-34$ (2d ed. 1984).

Standardized options on stocks, stock indexes, currencies, T-bills, commodity futures, currency futures, and stock index futures, among other instruments, are currently traded on the national exchanges. J. Cox \& M. Rubinstein, supra, at vii; Amihud, Ho \& Schwartz, supra, at 4. The overthe-counter markets offer a variety of other derivative securities. See, e.g., Gilberg, supra, at 1640-68.

3. The principal statutes regulating the securities markets are the Securities Act of 1933,15 U.S.C. $\S 77$ (1982 \& Supp. III 1985), and the Securities Exchange Act of 1934, 15 U.S.C. $\$ 78$ (1982 \& Supp. III 1985) [hereinafter 1934 Act]. The principal statute regulating the futures market is the Commodities Exchange Act of 1936, 7 U.S.C. $\$ \S 1-26$ (1982 \& Supp. III 1985). These statutes were enacted to curb the abusive practices that contributed to the stock market crash of 1929 and the Great Depression. H.R. REP. No. 626, supra note 2, at 3. With the advent of futures on financial instruments, the functional distinction between securities and futures is blurring. The Securities \& Exchange Commission (SEC) and the Commodity Futures Trading Commission (CFTC) are currently embroiled in a bitter turf battle over regulation of stock index futures. Nash, Index Futures Causing Turf Battle, N.Y. Times, Feb. 4, 1988, at D1, col. 3; see also L. Loss, Fundamentals of SecurITIES REGULATION 235-43 (2d ed. 1988) (describing development of current "treaty" between SEC and CFTC over regulation of financial futures and options); Scarff, The Securities and Commodities Markets: A Case Study in Product Convergence and Regulatory Disparity, in MARKET Making, supra note 2, at 183-203 (comparing securities and commodities regulatory schemes).

4. Before the SEC authorized the listing of options on the Chicago Board Options Exchange (CBOE) in 1973, see In re Chicago Board Options Exchange, Exchange Act Release No. 9985, [1972-1973 Transfer Binder] Fed. Sec. L. Rep. (CCH) I 79,212, at 82,669 (Feb. 1, 1973), option trading was conducted solely over-the-counter. Although investor interest gradually increased through the late 1960 s, volume seldom exceeded one percent of the volume of the New York Stock Exchange (NYSE). See J. Cox \& M. Rubinstein, supra note 2, at 23; Robert R. Nathan Associates, Inc., 
these new securities presents an unprecedented challenge to this venerable regulatory framework: Can these statutes deal effectively with the complicated market relationships created by derivative securities?

This Note argues that they can-but only if the federal courts improve their understanding of the purpose and effects of derivative securities trading. The Note focuses on the courts' efforts to interpret one of the most important regulatory statutes-section 10(b), the "catchall" antifraud provision of the Securities Exchange Act (the Act), ${ }^{6}$ and Rule 10b-5 promulgated thereunder ${ }^{7}$-in cases involving stock options, the first stan-

Public Policy Aspects of a Futures-Type Market in Options on Securities 23 (Nov. 1969) (study prepared for the Chicago Board of Trade) [hereinafter CBT Study], reprinted in PLI CoRporate Law and Practice Course Handbook Series No. 146, Option Trading 99, 129 (1974). The options traded on the exchanges are referred to as "listed" options. They differ from conventional options in a number of important respects. Conventional options are negotiated individually, whereas listed options have standardized terms (e.g., striking price, time to expiration). Moreover, the value of conventional options depends on the solvency of the seller, whereas all listed options are guaranteed by the issuer, the well-financed Options Clearing Corporation (OCC). J. Cox \& M. Rubinstein, supra note 2, at 23-26; Carasick, Mechanics and Regulation of Options Trading, in HaNDBOok of Financial Markets: Securities, Options, Futures 575-84 (F. Fabozzi \& F. Zarb eds. 1981) [hereinafter MARKET HANDBOok]. Before the advent of listed options, transaction costs were high and options were seldom resold. J. Cox \& M. RuBinsteIN, supra note 2, at 23-26; CBT Study, supra, at 2, 21, 31. The options exchanges were designed on the model of the futures exchanges to create a secondary, or resale, market for options. CBT Study, supra, at 31-42. The fungibility of listed options makes possible open-market trading throughout the exercise period.

The stocks underlying all listed options are actively traded, primarily on the NYSE. J. Cox \& M. RuBINSTEIN, supra note 2, at vii. The stringent listing requirements, see Carasick, supra, at 583-84, assure a deep and liquid market in the underlying stock and the availability of adequate information about the issuer of the stock through routine corporate disclosure.

Stock options are currently traded on the CBOE, the American Stock Exchange, the Philadelphia Stock Exchange, the Pacific Stock Exchange, and the NYSE. STAFF OF THE SEC, The October 1987 Market Break 8-1 (Feb. 1988), reprinted in [Current Binder] Fed. Sec. L. Rep. (CCH) No. 1271 (Feb. 9, 1988) (extra edition). Options on a combined total of over 500 different stocks are currently traded on the exchanges. N.Y. Times, Mar. 2, 1988, at D9, col. 3, D13, cols. 1-8.

After successful experiments with listed stock option trading, the exchanges introduced options on other financial instruments. J. Cox \& M. RuBinstein, supra note 2, at vii. Over $43 \%$ of the total volume in option contracts from January to October 1987 was in stock index options. STAFF OF THE SEC, supra, at 3-1 \& n.3. Unless otherwise indicated, the term "options" as used in this Note denotes listed stock options.

5. Section 10 (b) reads in relevant part:

It shall be unlawful for any person ...

(b) To use or employ, in connection with the purchase or sale of any security . . ., any manipulative or deceptive device or contrivance in contravention of such rules and regulations as the Commission may prescribe as necessary or appropriate in the public interest or for the protection of investors.

15 U.S.C. $\S 78 \mathrm{j}(\mathrm{b})(1982)$.

6. See, e.g. . Chiarella v. United States, 445 U.S. 222, 226 (1980); Ernst \& Ernst v. Hochfelder, 425 U.S. 185,203 (1976).

7. Rule 10b-5 was adopted in 1942. See Exchange Act Release No. 3230 (May 21, 1942). As amended, the Rule reads in relevant part:

It shall be unlawful for any person . . .

(a) To employ any device, scheme, or artifice to defraud,

(b) To make any untrue statement of a material fact or to omit to state a material fact necessary in order to make the statements made, in the light of the circumstances under which they were made, not misleading, or

(c) To engage in any act, practice, or course of business which operates or would operate as a fraud or deceit upon any person, in connection with the purchase or sale of any security. 
dardized option contracts to play a major role on the exchanges. ${ }^{8}$

Section I describes the three approaches to standing developed in the option trader $^{\ominus}$ cases. Section II refutes the economic arguments offered to support denial of standing in some of these cases. This Section seeks to clarify the economic functions served by derivative securities and to explain their essential similarity to familiar corporate securities. Section III argues that the use of a doctrinal limitation-the fiduciary principle ${ }^{10}$ - to deny standing in these cases distorts the relevant precedent and substitutes reflexive reliance on traditional categories of fiduciary relationships for careful analysis of the purpose underlying the fiduciary limitation. Such an analysis demonstrates that option traders should have standing under Rule $10 \mathrm{~b}-5$ to the same extent as stockholders.

\section{The Option Trader Gases}

Since the introduction of listed stock options in 1973, several district courts and two circuit courts have examined whether option traders have standing to sue corporations or their insiders ${ }^{11}$ under section $10(\mathrm{~b})$ and Rule 10b-5. These cases have involved either or both of two different causes of action: insider trading ${ }^{12}$ and misrepresentation. ${ }^{13}$ The courts have developed three approaches to the standing problem, two of which fail to distinguish between the two causes of action.

The first approach, now constituting a minority of the cases, is simply to observe that the Act defines options as securities ${ }^{14}$ and thereby to con-

17 C.F.R. $\S 240.10 \mathrm{~b}-5$ (1987).

8. See supra note 4.

9. As used in this Note, the term "option trader" refers to both option writers and option holders.

10. This term is borrowed from Langevoort, Insider Trading and the Fiduciary Principle: $A$ Post-Chiarella Restatement, 70 Calif. L. Rev. 1 (1982).

11. As used in this Note, the term "insiders" refers to traditional corporate insiders, such as officers, directors, and control persons, and to their tippees. See, e.g., L. Loss, supra note 3, at $739-40$.

12. Insider trading under Rule $10 \mathrm{~b}-5$ is the failure of a corporate insider to disclose material inside information about the corporation before trading in the corporation's securities. Some economists have argued that insider trading should not be prohibited because it helps securities prices to approach their true value and gives management an incentive to maximize share values. See, e.g., $H$. Manne, Insider Trading and the Stock Market 77-158 (1966); Carlton \& Fischel, The Regulation of Insider Trading, 35 STaN. L. REv. 857, 861-72 (1983); Wu, An Economist Looks at Section 16 of the Securities Exchange Act of 1934, 68 Colum. L. REv. 260, 265-69 (1968). For the purposes of this Note, it is assumed that insider trading undermines public confidence in the fairness of securities markets, thereby decreasing allocational efficiency, and that private actions for damages effectively deter the practice. See, e.g., Brudney, Insiders, Outsiders, and Informational Advantages Under the Federal Securities Laws, 93 HARv. L. Rev. 322, 353-57 (1979).

13. Misrepresentation is a corporation's misstatement or misleading omission of material information to which investors in the corporation are entitled. A misrepresentation claim need not involve any trading by an insider. The term "omission" is used in this Note to indicate a failure to disclose that is characterized as a misrepresentation; "nondisclosure" is used to indicate the failure to disclose that is involved in insider trading. An omission is akin to a half-truth, in contrast to a lie (an affirmative misstatement) or complete silence (nondisclosure).

14. Since 1982, the definition of a security in section $3(a)(10)$ of the Act has included the following language: "The term 'security' means ... any put, call, straddle, option, or privilege on any security . . ." 15 U.S.C. \& $78 \mathrm{c}(\mathrm{a})(10)(1982)$. Prior to amendment, the definition included "any 
clude that option traders have standing to pursue their claims under Rule 10b-5. This Note will term the cases adopting this approach the "plain language" cases. $^{15}$

The second and most prevalent approach initially appeared in insider trading cases in the wake of the Supreme Court's landmark decision in Chiarella $v$. United States ${ }^{16}$ but has since been applied in misrepresentation cases as well. On the basis of both policy and failure to meet the fiduciary duty requirement established by Chiarella ${ }^{17}$ these cases usually deny option traders standing under Rule $10 \mathrm{~b}-5$, even though such plaintiffs fall within the literal coverage of the Rule. The cases adhering to this approach will be termed the "fiduciary" cases. ${ }^{18}$

The third and newest approach, represented by only one case, is essentially a refinement on the first. This case will be termed the "modified plain language" case. ${ }^{10}$

\section{A. The Plain Language Cases}

The plain language cases look exclusively to the text of the controlling statute to determine the standing of option trader plaintiffs. Noting that the Act's definition of a security includes options, these courts conclude that option trader plaintiffs, as purchasers or sellers of a "security," have standing to bring a claim under Rule $10 \mathrm{~b}-5 .^{20}$

.. . warrant or right to subscribe to or to purchase a security . . . ." 15 U.S.C. § 78c(a)(10) (1976). By the time of the earliest option trader case, the Supreme Court had interpreted the pre-amendment definition to extend to both put and call options. Blue Chip Stamps v. Manor Drug Stores, 421 U.S. 723, 751 (1975); cf. H.R. REP. No. 626, supra note 2, at 3 ("Because of the need to reach a wide range of instruments marketed to public investors, the term 'security' was broadly defined.").

15. The plain language cases are In re Digital Equip. Corp. Sec. Litig., 601 F. Supp. 311 (D. Mass. 1984) (misrepresentation); Backman v. Polaroid Corp., 540 F. Supp. 667 (D. Mass. 1982) (insider trading); Lloyd v. Industrial Bio-Test Laboratories, 454 F. Supp. 807 (S.D.N.Y. 1978) (misrepresentation). An earlier case involving options issued by the defendant corporation, Wulc v. Gulf \& Western Indus., 400 F. Supp. 99 (E.D. Pa. 1975), also falls into the plain language category.

16. 445 U.S. 222 (1980) (employee of financial print shop, who had decoded confidential information about impending corporate takeovers and traded in securities of target company, was not guilty of insider trading under section 10(b) because he was not fiduciary for target company's shareholders).

17. Id. at 228. Chiarella and a later case, Dirks v. SEC, 463 U.S. 646 (1983), established that the defendant in a Rule $10 \mathrm{~b}-5$ insider trading enforcement action cannot be held liable unless he breached a fiduciary duty through his trading, 445 U.S. at 232 , or traded on the basis of a tip that violated the tipper's fiduciary duty, 463 U.S. at 661.

18. The fiduciary cases are Laventhall v. General Dynamics Corp., 704 F.2d 407 (8th Cir.) (insider trading), cert. denied, 464 U.S. 846 (1983); Starkman v. Warner Communications, 671 F. Supp. 297 (S.D.N.Y. 1987) (misrepresentation); Deutschman v. Beneficial Corp., 668 F. Supp. 358 (D. Del. 1987) (misrepresentation), rev'd, [Current Binder] Fed. Sec. L. Rep. (CCH) I 93,655, at 98,009 (3d Cir. Mar. 7, 1988); Bianco v. Texas Instruments, 627 F. Supp. 154 (N.D. Ill. 1985) (insider trading and misrepresentation); In re McDonnell Douglas Corp. Sec. Litig., 567 F. Supp. 126 (E.D. Mo. 1983) (insider trading and nondisclosure); O'Connor \& Assocs. v. Dean Witter Reynolds, Inc., 529 F. Supp. 1179 (S.D.N.Y. 1981) (insider trading).

19. Deutschman v. Beneficial Corp., [Current Binder] Fed. Sec. L. Rep. (CCH) II 93,655, at 98,009 (3d Cir. Mar. 7, 1988).

20. In re Digital Equip. Corp. Sec. Litig., 601 F. Supp. 311, 315 (D. Mass. 1984); Backman v. Polaroid Corp., 540 F. Supp. 667, 671 (D. Mass. 1982); Lloyd v. Industrial Bio-Test Laboratories, 454 F. Supp. 807, 811 (S.D.N.Y. 1978); see supra note 14. In Lloyd, the court also observed that the 
These cases offer no analysis beyond the text of the statute to support granting standing to the option trader plaintiff. One of them is a postChiarella insider trading case, yet the opinion makes no mention of the fiduciary principle. ${ }^{21}$

While the plain language cases adopt the result advocated by this Note, they fail to rebut or even to acknowledge the policy objections to granting standing articulated by the fiduciary cases. This failure prevents the plain language cases from either stemming the growing tide of fiduciary cases or providing insight into the role of the Act's antifraud provisions in derivative securities markets. ${ }^{22}$ Moreover, silence on the issue of fiduciary duty, while appropriate in misrepresentation cases ${ }^{23}$ is inadequate in cases of insider trading. After Chiarella, it is simply impossible to discuss standing to bring an insider trading claim without coming to terms with the fiduciary principle. ${ }^{24}$

\section{B. The Fiduciary Cases}

Although the fiduciary courts recognize that options are "securities" for the purposes of section 10(b), ${ }^{25}$ they argue that the standing question cannot be resolved solely by reference to the text of the statute. ${ }^{28}$ Drawing on both their understanding of the economics of option trading and their reading of Chiarella, they offer several reasons for resolving the issue in favor of the defendant in most cases.

First, these courts stress the speculative nature of option trading: "[T]he options trader makes the decision to assume greater risk in order to garner greater returns. We do not feel obligated to expand the scope of liability under $\S 10(\mathrm{~b})$ to make this obviously uncertain market safer . . .."27

statute is not restricted to issuers of securities. 454 F. Supp. at 811.

21. See Backman, 540 F. Supp. at 667.

22. Inquiry into standing under a federal statute ultimately focuses, of course, on legislative intent. Touche Ross \& Co. v. Redington, 442 U.S. 560, 568 (1979). In relying on the literal language of section $10(\mathrm{~b})$ and Rule $10 \mathrm{~b}-5$, the plain language cases fail to explore whether Congress intended these regulations to cover new markets whose development was unforeseen at the time of enactment. Since intent is difficult to glean from the scanty legislative history, see, e.g., Basic, Inc., v. Levinson, [Current Binder] Fed. Sec. L. Rep. (CCH) IJ 93,645, at 97,954 (U.S. Mar. 7, 1988) (White, J., concurring in part and dissenting in part), it must be inferred by asking whether conferring standing in this new situation is consistent with the purposes of the legislative scheme. Such an inquiry will necessarily entail examination of the role of option trading in the markets regulated by the 1934 Act and the need of option traders for the protections enjoyed by other investors under Rule 10b-5.

23. See infra text accompanying notes 110-22.

24. See Langevoort, supra note 10 , at 23.

25. See Laventhall v. General Dynamics Corp., 704 F.2d 407, 410 (8th Gir.), cert. denied, 464 U.S. 846 (1983); Starkman v. Warner Communications, 671 F. Supp. 297, 306 (S.D.N.Y. 1987); Deutschman v. Beneficial Corp., 668 F. Supp. 358, 362 (D. Del. 1987), rev'd, [Current Binder] Fed. Sec. L. Rep. (CCH) I] 93,655, at 98,009 (3d Cir. Mar. 7, 1988); O'Connor \& Assocs. v. Dean Witter Reynolds, Inc., 529 F. Supp. 1179, 1186 (S.D.N.Y. 1981).

26. See, e.g., Deutschman, 668 F. Supp. at 360 ("Some background explanation of options is essential to understanding the question of whether options traders have standing . . . .").

27. Bianco v. Texas Instruments, 627 F. Supp. 154, 161 (N.D. Ill. 1985); see Laventhall, 704 F.2d at 410-11; Starkman, 671 F. Supp. at 300, 307; Deutschman, 668 F. Supp. at 361, 364. 
Second, the courts distinguish the relationship of the corporation to its shareholders from that of the corporation to an option holder. The cases note that the corporation is not the issuer of the options and does not consent to their issuance. ${ }^{28}$ Nor does the option, unlike a share of stock, represent a contribution of capital to the corporation. ${ }^{29}$ Consequently, "[t]he common stock issuer . . . derives no financial benefit from the options transactions, and in fact may be harmed inasmuch as the options market draws purchasers who might otherwise buy common stock . . ." Moreover, the corporation does not control the number of option writers; "its potential liability to options holders is limited only by the whims of the option writers." Since "the brute fact is the corporation is run only for the benefit of shareholders, not options traders," the corporation and its insiders owe the option holder no special duty of disclosure. ${ }^{32}$ Regardless of the type of claim-insider trading or misrepresentation-the courts argue that the Supreme Court's opinions in Chiarella and Dirks v. $S E C^{3 s}$ require the existence of a fiduciary relationship between plaintiff and defendant before such a duty of disclosure will arise under Rule 10b-5. ${ }^{\text {st }}$

Third, the courts look to the difficulty of proving causation. They characterize the relationship between the defendant's trades or misrepresentations and the plaintiff's loss as "speculative," "indirect," and "remote." In the absence of any "transactional nexus" between the defendant and the option trader, the courts hold that the plaintiff's claim must fail..$^{35}$

Although the fiduciary courts find that these three reasons compel denial of standing in all misrepresentation and many insider trading cases, the courts do grant standing in one type of insider trading case, which this Note terms the "O'Connor exception."

In the earliest fiduciary options case, $O^{\prime}$ Connor $\&$ Associates $v$. Dean Witter Reynolds, Inc. ${ }^{38}$ the defendants traded on inside information about

28. Laventhall, 704 F.2d at 411; Starkman, 671 F. Supp. at 304, 307; Deutschman, 668 F. Supp. at 360; Bianco, 627 F. Supp. at 159.

29. Laventhall, 704 F.2d at 411 (quoting O'Connor, 529 F. Supp. at 1184-85); Starkman, 671 F. Supp. at 304; Deutschman, 668 F. Supp. at 362.

30. Bianco, 627 F. Supp. at 159.

31. Id. at 161; see Starkman, 671 F. Supp. at 307 (quoting Bianco); Deutschman, 668 F. Supp. at 364.

32. Deutschman, 668 F. Supp. at 362; see Laventhall, 704 F.2d at 411 (quoting O'Connor, 529 F. Supp. at 1184-85).

33. 463 U.S. $646(1983)$.

34. Laventhall, 704 F.2d at 411-12; Starkman, 671 F. Supp. at 302-04; Deutschman, 668 F. Supp. at 361-62; Bianco, 627 F. Supp. at 161; In re McDonnell Douglas Corp. Sec. Litig., 567 F. Supp. 126, 127 (E.D. Mo. 1983).

35. Laventhall, 704 F.2d at 412 (corporation's insider trades in stock had no "transactional nexus" with plaintiff's option trades, and its "alleged illegal gain is remote and totally speculative in relation to plaintiff's loss"); Starkman, 671 F. Supp. at 306; Deutschman, 668 F. Supp. at 363; Bianco, 627 F. Supp. at 161 . The cases do not specify whether the term "transactional nexus" refers to an absence of privity between the parties, a lack of causation in fact, or both.

36. 529 F. Supp. 1179 (S.D.N.Y. 1981). 
an impending corporate takeover by purchasing call options on the target company's stock. ${ }^{37}$ As in the cases discussed above, the O'Connor court finds that no fiduciary relation exists between the option writer plaintiffs and the insider defendants. ${ }^{38}$ Nonetheless, the court confers standing because the defendants traded not in the stock market, ${ }^{39}$ but in the options market. Accepting the plaintiff's argument that denial of standing in this situation would leave "a broad loophole in the rules against insider trading," 10 the court concludes that "by virtue of their fiduciary duty to the corporation and its shareholders, corporate insiders become subject to the separate duty to either 'abstain or disclose.' Unlike the fiduciary duty, which is owed only to the corporation and its shareholders, this additional duty to disclose is owed 'to the investing public' . . .."41

To reach this result, the $O^{\prime}$ Connor court relies on the so-called misappropriation theory adopted by the Second Circuit in United States $v$. Newman. ${ }^{42}$ Analogizing from Newman, in which a non-insider was convicted of insider trading because he breached a fiduciary duty to his employer, even though he owed no duty to those with whom he traded, the court reasons that, once the defendants breach their fiduciary duty to somebody, somebody else to whom that duty was not owed can sue them for the breach, provided that the claimant can show injury from the breach. ${ }^{43}$ Following O'Connor, one court has granted standing to bring an insider trading claim where the defendant traded in options, while denying standing to bring a misrepresentation claim arising from the same facts. ${ }^{44}$

Taken together, the fiduciary cases establish a hybrid standing rule: If

37. See id. at $1182-83$.

38. Id. at 1184-85. The O'Connor court does not rely on the risk or remoteness theories of the later Laventhall and Bianco opinions, although it does discuss arguments raised by the parties about risk. See id. at 1183-84.

39. In Laventhall, the leading fiduciary case, the defendant corporation traded in the stock market, whereas the plaintiff traded in the options market. 704 F.2d at 413 (distinguishing $O^{\prime}$ Connor).

40. O'Connor, $529 \mathrm{~F}$. Supp. at 1188 . The plaintiff claimed that if option traders were not able to sue corporate insiders for insider trading in options, shareholders would not be able to either, leaving insiders free to trade on undisclosed corporate information with impunity. See infra note 106.

41. Id. at 1187 (quoting Shapiro v. Merrill Lynch, Pierce, Fenner \& Smith, 495 F.2d 228, 240 (2d Cir. 1974)) (emphasis in original).

42. 664 F.2d 12 (2d Cir. 1981), cert. denied, 464 U.S. 863 (1983) (discussed in O'Connor, 529 F. Supp. at 1185); see Carpenter v. United States, 108 S. Ct. 316 (1987) (evenly divided Court affirms conviction under section 10(b) based on misappropriation theory); see also 3 A. BromBERG \& L. Lowenfels, Securities Fraud AND Commodrmes Fraud § 7.5(513), at 7:241-42 (1986) (criticizing theory). As originally conceived, the misappropriation theory was addressed to situations like that in Chiarella and Newman, where the criminal defendant was not a traditional corporate insider but had breached a fiduciary duty - not to shareholders of the corporation in whose securities he traded, but to his employer. Even though the defendant in such a case breaches his trust to a party unconnected with the trading or issuance of the securities in which he trades, the misappropriation theory proposes that he is guilty of insider trading under Rule 10b-5. This paradigmatic situation is of course quite different from that in $O^{\prime}$ Connor, where the defendant was a traditional insider and the case was not a criminal or enforcement action but a private suit. See infra notes 105-06 and accompanying text.

43. See O'Connor, 529 F. Supp. at 1185-86.

44. Bianco v. Texas Instruments, 627 F. Supp. 154, 163-64 (N.D. Ill. 1985). 
the defendant traded in stock or made misleading disclosures, option traders are denied standing because the defendant does not owe them a fiduciary duty, but if an otherwise identical defendant traded in options, option traders may sue her for breach of a "separate," derivative duty owed to the investing public.

\section{The Modified Plain Language Case}

Recently, the Third Circuit gave reason to hope that the plain language approach might be elaborated into a comprehensive response to the fiduciary cases. In reversing the fiduciary opinion of the court below in Deutschman $v$. Beneficial Corp. ${ }^{45}$ the circuit court drew a sharp distinction between insider trading cases, to which the fiduciary principle applies, and misrepresentation cases, to which it does not apply. ${ }^{46}$ Regrettably, the court did not dispose of the economic arguments adopted by the district court with the same clarity and decisiveness, deferring instead to Congress's judgment that option trading has social benefits. ${ }^{47}$

Section II of this Note takes up the challenge sidestepped by the Third Circuit: dispelling the misconceptions of the options markets that inform the fiduciary courts' reluctance to grant standing to option traders.

\section{A Corrective View of the Options Market}

Unlike the plain language cases, the fiduciary cases treat the economics of option trading as essential to determining the standing of option traders under Rule $10 \mathrm{~b}-5 .^{48}$ Although these courts are correct in recognizing that application of section 10 (b) to a new market demands that courts undertake this traditionally legislative inquiry, ${ }^{49}$ their understanding of the role of options in modern securities markets is seriously misguided. Ignoring the economic benefits of option trading, these courts allow vague prejudices against speculative securities and simplistic analyses of market relationships to contract the scope of Rule 10b-5.

\section{A. The Role of Risk in Option Trading}

As discussed above, the fiduciary courts argue that option traders, having chosen to invest in a speculative security, cannot ask the courts to

45. [Current Binder] Fed. Sec. L. Rep. (CCH) I 93,655, at 98,009 (3d Cir. Mar. 7, 1988), rev'g 668 F. Supp. 358 (D. Del. 1987). Like the plain language cases, this opinion begins with the text of the statute. $I d$. at 98,010 . Unlike them, it goes on to address the rationales of the court below, which typify those of the fiduciary courts.

46. Id. at $98,011-12$.

47. Id. at 98,012 .

48. The modified plain language court, while offering a tentative rebuttal of the unflattering portrait of the options market painted by the court below, regards the question as a matter for the legisiature to determine. $I d$.

49. See supra note 22 . 
protect them from the consequences of their choice. ${ }^{50}$ This view is illconsidered in two respects. First, it overlooks the valuable function of the options market in transferring risk from the stock market. Second, it blurs the distinction between the risk of an investment and the risk of fraud.

\section{The Risk of the Options Market Benefits the Stock Market}

Options may be used either to reduce or to increase the risk of an investor's stock portfolio. ${ }^{52}$ For example, institutional investors and individuals with large portfolios may hedge their stockholdings by writing covered calls. ${ }^{52}$ Since most options are never exercised, ${ }^{53}$ such an investor enhances the yield of its portfolio by pocketing the premiums on option sales. If the value of its portfolio declines, these premiums offset some of the loss. If the value of the underlying stock rises to the point where exercise will occur, the investor will not benefit from the full appreciation of its stock, but it will still sell to the option holder at a profit. By reducing the difference between the worst and the best possible outcomes of the writer's stock position, this hedging technique reduces the risk of its portfolio. ${ }^{54}$

Individuals with a taste for high-risk, high-yield investments tend to be on the other side of this transaction. ${ }^{65}$ Rather than investing in short-term

50. See Starkman v. Warner Communications, 671 F. Supp. 297, 302, 307 (S.D.N.Y. 1987) Deutschman v. Beneficial Corp., 668 F. Supp. 358, 364 (D. Del. 1987), rev'd, [Current Binder] Fed. Sec. L. Rep. (CCH) If 93,655, at 98,009 (3d Cir. Mar. 7, 1988); Bianco, 627 F. Supp. at 161; see also 3 A. BROMBERG \& L. LowENFELS, supra note $42, \S 7.5(312)$, at 7:215 (judges reluctant to put in motion costly machinery of securities fraud trial for benefit of speculators); cf. Francis, Speculative Markets: Valuable Institutions or Dens of Inequity?, in MARKET HANDBOOK, supra note 4, at 692-700 (arguing against widespread perception that speculative markets serve no useful function). The apparent lack of sympathy on the part of the federal judiciary for speculators in general and option traders in particular may have historical roots. Options were associated with many of the securities abuses of the 1920s, and during the hearings on the 1934 Act, Congress considered a version of the bill that would have banned option trading altogether. H.R. 7855, $\S 9,73 d$ Cong., 2d Sess. (1934), reprinted in 10 Legislative History of the Securities ACT Of 1933 aND SeCuRItIES EXCHANGe ACT of 1934 (J. Ellenberger \& E. Mahar eds. 1973). In the hearings, "speculation" was used virtually synonymously with "manipulation" and "gambling." See, e.g., 78 ConG. REC. 7863 (1934) (remarks of Rep. Wolverton); 78 CoNG. REC. 8387 (1934) (remarks of Sen. Bulkley). It was neither speculation per se nor the risk of the option contract, however, but the unregulated market of the time that allowed options to become instruments of abuse. See infra note 58 and text accompanying notes 63-64.

51. For an overview of the most common option investment strategies, see STAFE OF THE SEC, 96th Cong., Ist SesS., Report of the Special Study of the Options Markets 107-20, 147-64 (House Comm. on Interstate and Foreign Commerce Print 1979) [hereinafter Options STUDy]; see also Hunter, Arbitrage Trading, in MARKeT MAKING, supra note 2, at 145-50 (describing use of derivative securities to increase informational content of market prices and consolidate markets).

52. See G. Gastineau, The Stock Options Manual 196 (2d ed. 1979). These calls are said to be "covered" because the writer already owns the stock that it will have to deliver if the holder exercises the option. Institutional investors are often restricted by law from using other option investment strategies. See generally Gordon, Market Participants: Institutions, in Market Handbook, supra note 4, at 593-607 (describing effect of "prudent man" rule on use of options by various institutions).

53. An estimated $5.1 \%$ of listed options are exercised. Options Study, supra note 51 , at 76 .

54. See, e.g., Gastineau, The Risk/Reward Characteristics of Options and Options Portfolios, in MARKET HANDBOOK, supra note 4, at 561.

55. See G. Gastinenu, supra note 52, at 196. 
stock price movements directly by buying stock, these investors prefer to invest a smaller amount of capital in market fluctuations by purchasing options. ${ }^{56}$ If the option expires unexercised, the holder may lose her relatively modest investment, but if the stock price changes enough to warrant exercise of the option, she may realize a potentially limitless return. Unlike stockholders, who demand a premium for bearing undiversifiable risk, option holders prefer options on volatile stocks, because these stocks are most likely to change dramatically in price before expiration of the option. If the price changes in the right direction, the option holder will exercise and make a profit; if not, she can lose no more than the premium. ${ }^{67}$

The options market allows investors to transfer risk from shareholders, who want to reduce the risk of their portfolio, to option holders, who want to augment it. By allowing investors to adjust the risk of their holdings to their liking, the options market makes the stock market attractive to more investors. ${ }^{58}$ The options market thus enhances the depth ${ }^{58}$ and liquidity ${ }^{60}$ of the stock market, maximizing stock prices ${ }^{\mathbf{6 1}}$ and lowering the corpora-

56. See, e.g., J. Cox \& M. Rubinstein, supra note 2, at 50-52 (describing use of options to take leveraged position in stock market).

57. See, e.g., R. Brealey \& S. Myers, supra note 2, at 443.

58. In United States v. Dial, 757 F.2d 163 (7th Cir.), cert. denied, 474 U.S. 838 (1985), Judge Posner describes the similar benefits of commodities futures trading: "What we have described is speculation but not . . gambling. Commodity futures trading serves a social function other than to gratify the taste for taking risks .... [I]t enables the risk-averse to hedge against future uncertainties." Id. at 165.

As Judge Posner points out, speculation differs from gambling. Gambling involves creating a risk solely for the purpose of betting on the outcome; for example, in deciding to play poker, one elects to bear a risk that would not otherwise exist. Option or futures trading, in contrast, involves shifting a risk that inevitably attends economic activities; for example, the purchase of a call option does not create the risk that the underlying stock will lose value, but merely transfers it. E.g., Francis, supra note 50, at 693; N. WEINER, STOCK INDEX Futures 2-4 (1984).

59. "Depth" refers to the amount of interest in buying or selling a security at any given time. If a market is "deep," there are at any moment a large number of traders on either side of a transaction who will not have to waste resources on finding a willing buyer or seller, and transaction costs will decline. See Report of Special Study of Securities Markets of the Sec. \& Exch. Comm'N, Part 2, H.R. Doc. No. 95, 88th Cong., 1st Sess. 17 (1963).

60. "Liquidity" refers to the ease with which a seller can find a buyer and vice versa at a mutually agreeable price. Id. at 16; see also Schreiber \& Schwartz, Efficient Price Discovery in a Securities Market: The Objective of a Trading System, in MARkET MAKING, supra note 2, at 19, 25-26 (describing three aspects of liquidity); $W_{u}$, supra note 12, at 263-64 (describing characteristics of liquid market). Liquidity is related to depth, in that a market in which a large number of buyers and sellers are active will also be one in which buyers and sellers can readily enter into transactions with each other. Since investors usually prefer assets that can be sold quickly and cheaply, increased liquidity will enhance stock values.

61. See Exchange Act Release No. 22,026, 33 SEC Docket (CCH) 18, 24 (May 8, 1985) (option trading can add depth and liquidity); Hayes \& Tennenbaum, The Impact of Listed Options on the Underlying Shares, 8 FIN. MGMr. 72, 74-76 (Winter 1979) (option trading increases volume in underlying shares); Hunter, supra note 51, at 145; Klemkosky \& Maness, 6 J. PortFolio Mgmt. 12,16 (Winter 1980) (listed options create more efficient market for underlying shares); $c f$. STAFF of THE SEC, supra note 4, at 3-4 to -6 (trading in derivative index products adds substantial liquidity and pricing efficiency to equity markets); Ross, Options and Efficiency, 90 Q.J. EcoN. 75 (1976) (theoretical exploration of use of options to improve efficiency). Some financial analysts believe that option trading increases volatility in the underlying stock or draws equity capital away from over-thecounter stocks and new issues. Neither studies by the SEC nor those commissioned by the CBOE have found evidence of these effects. See Exchange Act Release No. 22,026, supra; Management Analysis 
tion's cost of capital. ${ }^{62}$

\section{The Distinction Between the Risk of an Investment and the Risk of Fraud}

Different investments involve different degrees of risk. Investors choose one investment over another based on their own attitudes toward risk. The investor who prefers high-risk, high-yield securities such as options takes the full risk inherent in her chosen financial instrument. But these voluntarily assumed risks are a function of the terms of the investment contract and the health of the firm in which she invests. No investor chooses to take the additional risk of fraud.

The fiduciary cases presume that in asking for standing to sue for fraud under Rule 10b-5, option traders want the defendant to insure them against loss in an admittedly uncertain market. ${ }^{63}$ This view confuses the risk of an investment with the risk of fraud. A primary purpose of the federal securities laws is to insure that no investor, regardless of her individual risk preferences, has to take the risk of fraud. ${ }^{84}$

\section{B. The Option Trader's Relationship to the Corporation}

A second feature of the options market that is misunderstood by the fiduciary courts is the option trader's relationship to the corporation on whose stock she has purchased options. The most decisive aspect of this relationship-the lack of a fiduciary duty running from the corporation to the option trader-is discussed in Section III below. Two other aspects of the relationship also command these courts' attention: The corporation does not issue the options, and option traders do not contribute capital to

Center, The Impact of Exchanged-Traded Options on the Market for New Issues of Common Stock of Small Companies (June 1977) (available from CBOE); Robert R. Nathan Associates, Inc., Review of Initial Trading Experience at the Chicago Board Options Exchange (Dec. 1974) (same); see also Klemkosky \& Maness, supra, at 18 (option trading has negligible impact on risk of underlying securities). But of. STAFF of THE SEC, supra note 4, at 3-11 to -16 (index futures trading contributed to stock market volatility during October 1987 crash).

The benefits of risk transfer through options, futures, and related derivative securities extend to the economy as a whole. J. Cox \& M. RuBinstein, supre note 2, at 443-44 (options help align stock prices with true values, assisting efficient allocation of real resources, and provide information as to stock volatility); see K. ARROw, Insurance, Risk and Resource Allocation, in EsSAYS IN THE THEORY OF RISK-BEARING 134, 137-38 (1970).

62. See infra text accompanying notes 70-76.

63. See, e.g., Starkman v. Warner Communications, 671 F. Supp. 297, 302 (S.D.N.Y. 1987) ("Rule 10b-5 was not intended 'to establish a scheme of investor's insurance." (quoting List v. Fashion Park, Inc., 340 F.2d 457, 463 (2d Cir.), cert. denied, 382 U.S. 811 (1965))).

64. See, e.g., H.R. ReP. No. 1383, 73d Cong., 2d Sess. 4-6, 10-11 (1934). Investment in risky enterprises, even highly speculative ones, serves a constructive social purpose. It attracts capital to uncertain but potentially worthwhile projects, such as new technology. Investment in fraud has no such social value. In fraud-ridden markets, it is impossible to allocate resources efficiently because the true value of securities is unknown. See id. at 11; cf. United States v. Dial, 757 F.2d 163, 165 (7th Cir.), cert. denied, 474 U.S. 838 (1985) (if traders in commodities futures market know that some people in market have preferential access to information such that trading is "rigged," "there will be less commodity futures trading, period, and the social benefits of such trading . . . will be reduced"). 
the corporation. In determining that these factors weigh against granting standing, the fiduciary courts misunderstand the economics of option trading and misinterpret the scope of Rule $10 \mathrm{~b}-5$.

\section{The Corporation Is Not the Issuer}

Currently, two clearing corporations are the only entities allowed to issue options on the exchanges. ${ }^{66}$ The corporation whose stock underlies an option does not control the number of options that may be written or the magnitude of its potential liability.

As both the Supreme Court and the plain language cases have pointed out, however, section $10(\mathrm{~b})$ is not by its express terms limited to issuers: "[A] $\S 10(\mathrm{~b})$ action can be brought by a purchaser or seller of 'any security' against 'any person' who has used 'any manipulative or deceptive device or contrivance' in connection with the purchase or sale of a security." ${ }^{B 8}$ If Congress had not intended this broad coverage, it would have made its intent explicit, as it did in other sections of the securities laws. ${ }^{87}$

Moreover, the corporation is the only party that can logically assume responsibility for most misinformation affecting option values. The clearing corporations that issue listed options have no special access to informa-

65. These are the OCC, which issues almost all of the options traded on the American exchanges, and Trans Canada Options, Inc. See Registration Statement and Other Disclosure Documents Related to Standardized Options, Exchange Act Release No. 18,836, [1982 Transfer Binder] Fed. Sec. L. Rep. (CCH) If 83,230, at 85,194 (June 24, 1982).

66. Herman \& MacLean v. Huddleston, 459 U.S. 375, 382 (1983) (contrasting scope of section 10(b) of 1934 Act to that of section 11 of 1933 Act, which limits liability to issuers) (emphasis supplied by Court); see Deutschman v. Beneficial Corp., [Current Binder] Fed. Sec. L. Rep. (CCH) I] 93,655, at 98,011 (3d Cir. Mar. 7, 1988); Lloyd v. Industrial Bio-Test Labaratories, 454 F. Supp. 807, 811 (S.D.N.Y. 1987).

One of the fiduciary cases, Deutschman v. Beneficial Corp., 668 F. Supp. 358 (D. Del. 1987), rev'd, [Current Binder] Fed. Sec. L. Rep. (CCH) I 93,655, at 98,009 (3d Cir. Mar. 7, 1988), argues that Blue Chip Stamps v. Manor Drug Stores, 421 U.S. 723 (1975), limits private actions under Rule 10b-5 to plaintiffs who have purchased or sold securities issued by the defendant. 668 F. Supp. at 362 . Although there is language in Blue Chip that loosely supports this reading, see 421 U.S. at 747, the Court also states quite explicitly that options to purchase or sell a security satisfy the Birnbaum test:

A contract to purchase or sell securities is expressly defined by $\S 3(\mathrm{a})$ of the $1934 \mathrm{Act}$. . .

as a purchase or sale of securities for the purposes of that Act. . . . [T] he holders of puts, calls, options, and other contractual rights or duties to purchase or sell securities have been recognized as "purchasers" or "sellers" of securities for purposes of Rule 10b-5 . . . because the definitional provisions of the 1934 Act themselves grant them such a status.

421 U.S. at 750-51 (citation omitted). The Court was surely well aware when it wrote these words that the issuer of an option or other contract to purchase or sell a security is seldom the same as the issuer of the underlying security. See Deustchman, I 93,655, at 98,012.

67. E.g., 15 U.S.C. $\$ \S 77 \mathrm{e}, 77 \mathrm{k}, 77 l, 77 \mathrm{q}$ (1982). Aside from Congressional intent, there is no reason why ability to control the magnitude of liability should be a prerequisite for amenability to suit under Rule 10b-5. The Rule addresses not mere negligence but knowing fraud. Ernst \& Ernst v. Hochfelder, 425 U.S. 185, 193 (1976). The defendant can control the extent of liability simply by refraining from engaging in the fraud. Moreover, the corporation's ability to control the extent of its liability to stockholders under Rule $10 \mathrm{~b}-5$ is scarcely greater. Once the firm's stock reaches the secondary market, its price is beyond the issuer's control. The issuer can affect the value of outstanding securities only by buying some of them back or by voluntarily "delisting," a drastic measure which will also have the effect of ending listed option trading. See also L. Loss, supra note 3, at 438 (issuer has no unqualified right to delist). 
tion about individual options and consequently make no representations about them. ${ }^{68}$ The value of an option depends on that of the underlying stock, ${ }^{89}$ and the best source of information about that stock is the issuing corporation. The issuer of the underlying stock is therefore the best source of information about the value of the option, and option traders are justified in relying on that information in making their investrnent decisions.

\section{Contribution of Capital}

Option traders do not contribute capital to the corporation. The fiduciary cases fail to acknowledge, however, that purchasers of stock in the secondary market do not either..$^{20}$ Once the stock enters the secondary market, gains and losses in value accrue only to sellers, not to the corporation. ${ }^{71}$

The options market differs from the stock market not in kind but in degree. ${ }^{72}$ From the corporation's point of view, the function of the secondary stock market is to augment the firm's ability to raise equity capital in the primary market. Investors will pay more for newly issued stock that can be cheaply and easily resold than for stock that cannot. ${ }^{73}$ The higher the stock price in the secondary market, the lower the corporation's cost of capital. ${ }^{74}$ The existence of a deep and liquid secondary market is therefore vital to the firm's ability to attract equity. The options market, by permitting investors to reallocate risk among themselves, enhances the depth and liquidity of the stock market. ${ }^{75}$ Like the secondary stock market, it too lowers the firm's cost of capital. ${ }^{76}$

\section{Remoteness of the Fraud}

According to the fiduciary cases, a further difficulty with granting standing to options traders under Rule $10 \mathrm{~b}-5$ is the "indirect" and "spec-

\footnotetext{
68. See 17 C.F.R. $\S 240.9 b-1$ (c) (1987).

69. See infra text accompanying notes 78-82.

70. See 3 A. BROMBERG \& L. LOWENFELS, supra note 42, § 7.5(312), at 7:210-11.

71. Reilly, Secondary Markets, in MARKET HANDBOOK, supra note 4, at 138.

72. Although stock, as an equity security, seems different in kind from a mere side bet between parties unrelated to the transaction, this distinction is not particularly meaningful in this context. All it tells us is that the corporation originally issued one instrument to raise equity capital and did not issue the other. The markets in both securities help the corporation to raise equity capital in the future; this is their fundamental similarity. In fact, the 1934 Act defines options as an "equity security." 17 C.F.R. § 240.3a11-1 (1987), promulgated under 15 U.S.C. § 78c(a)(11) (1982). Moreover, almost all corporate securities have an option feature. R. JARrow \& A. RudD, OptION PRICING 230 (1983); see also J. Cox \& M. Rubinstein, supra note 2, at 375-408 (discussing use of option pricing methods to value other corporate securities).

73. See Reilly, supra note 71, at 138 . The secondary market also determines the corporation's cost of capital, since new issues will be priced in accordance with the prevailing price in the secondary market. Id.

74. See, e.g., Wu, supra note 12, at 264; supra text accompanying notes 58-62.

75. See supra text accompanying notes 51-62.

76. See Deutschman v. Beneficial Corp., [Current Binder] Fed. Sec. L. Rep. (CCH) If 93,655, at 98,012 (3d Cir. Mar. 7, 1988).
} 
ulative" effect of misinformation or unlawful withholding of information ${ }^{27}$ about stock values on the options market. ${ }^{78}$ In fact, however, the impact of faulty disclosures on option prices is direct and calculable to a high degree of precision.

The amount that an investor will pay for an option is a function of five factors, including the price of the underlying stock. ${ }^{79}$ The formula used to quantify the interaction among these factors, the Black-Scholes option pricing model, has found almost universal acceptance in financial circles as an excellent predictor of option prices. ${ }^{80}$

Violations of Rule $10 \mathrm{~b}-5$ by corporations or insiders deceive option traders as to stock price. ${ }^{\mathbf{8 1}}$ Shareholder plaintiffs routinely demonstrate to the satisfaction of courts the effect of Rule $10 \mathrm{~b}-5$ fraud on the price of their stock. ${ }^{82}$ Once the impact of the fraud on the stock price has been determined, option trader plaintiffs can use the Black-Scholes option pricing model to demonstrate with comparable accuracy the impact of the fraud on the price of their options. If such losses can be calculated using standard valuation techniques, they can hardly be regarded as "merely speculative."

The analysis in this Section suggests that the options market benefits corporations and differs from conventional securities markets only in ways that are irrelevant to standing under Rule 10b-5. Section III examines a further similarity between options and conventional securities: their comparable status with respect to the fiduciary principle.

77. In most open-market insider trading cases, it is not the volume of inside trading itself that harms the plaintiff, but the plaintiff's inability to benefit from the impact that the information would have had on the stock price if it had been disclosed. See infra note 101.

78. See, e.g., Laventhall v. General Dynamics Corp., 704 F.2d 407, 412 (8th Cir.), cert. deried, 464 U.S. 846 (1983). But see Starkman v. Warner Communications, 671 F. Supp. 297, 302 (S.D.N.Y. 1987) (option value directly related to value of underlying security); Deutschman v. Beneficial Corp., 668 F. Supp. 358, 363 (D. Del. 1987) (same), rev'd, [Current Binder] Fed. Sec. L. Rep. (CCH) I 93,655, at 98,009 (3d Cir. Mar. 7, 1988).

79. The other factors are: (1) the striking price; (2) the risk-free rate of interest; (3) the time left before expiration; and (4) the volatility of the underlying stock. See, e.g., R. BREALEY \& S. MYERS, supra note 2, at 440-47; W. SHARPE, INVESTMENTs 441 (2d ed. 1981); OPtions STUDY, supra note 51, at 92-93. A sixth variable, payment of dividends, is also taken into account, but it is relatively unimportant. See, e.g., Gastineau, supra note 54, at 568; R. JARROw \& A. RuDD, supra note 72, at $16-17,138-39$.

80. The Black-Scholes model was introduced in Black \& Scholes, The Pricing of Options and Corporate Liabilities, 81 J. PoL. EcoN. 637 (1973), marking "the beginning of the modern theory of option pricing. . . . [It] has since become the industry standard." R. JARRow \& A. RuDD, supra note 72, at ix; see also id. at 140 ("[A]s a generality, the Black-Scholes pricing model works exceptionally well. There are few models in finance or economics that have such high predictive accuracy.").

81. The other factors affecting the price of the option tend to remain constant during the short period of time in which the fraud typically takes place.

82. Cases brought under Rule $10 \mathrm{~b}-5$ usually settle before the court can reach the issue of damages. Note, Rule 10b-5 Damage Computation: Application of Financial Theory to Determine Net Economic Loss, 51 FordhaM L. REv. 838, 838 n.2 (1983). Even among those cases that have reached the remedial phase, courts have accepted many different measures of recovery. Thompson, The Measure of Recovery Under Rule 10b-5: A Restitution Alternative to Tort Damages, 37 VAND. L. REv. $349,350-51$ \& n.2 (1984). 


\section{A Corrective View of the Fiduciary Principle in the Option Trader Cases}

Unlike analysis of the economics of option trading, interpretation of the fiduciary principle demands differentiation between insider trading and misrepresentation. This distinction has never been recognized in the plain language cases and has been lost in the fiduciary cases. The modified plain language case quite properly emphasizes it in rejecting the approach of the fiduciary cases.

\section{A. Insider Trading and the Fiduciary Principle}

As we have seen, the rule in the fiduciary insider trading cases is to deny standing because the defendant does not owe the option trader plaintiff a fiduciary duty to disclose inside information before trading on it. Yet there is an exception to the rule: When the defendant trades in options, not stock, the requirement of a fiduciary duty vanishes. This distinction is based on a misunderstanding of the significance of the fiduciary limitation and of the economic consequences of trading in the two situations.

Rule 10b-5 does not explicitly grant a cause of action for insider trading. Rather, the SEC and the courts have read into the Rule a prohibition against insider trading based on common-law fiduciary principles. ${ }^{88}$ In this common-law tradition, insider trading is considered a form of unjust enrichment. ${ }^{84}$ When a corporation chooses not to disclose information to the public in order to further a corporate purpose, insiders are barred from appropriating the undisclosed information for their own use by trading on it at the expense of those with whom they deal. ${ }^{85}$ The Supreme Court's decisions in Chiarella v. United States ${ }^{86}$ and Dirks v. SEC $C^{88}$ have limited this duty to "disclose or abstain" to defendants who breach a fiduciary duty by trading on inside information or who "inherit" a fiduciary duty from a tipper. Since these cases were initiated by the SEC, however, the implications of this fiduciary principle for the standing of private parties remain unclear. ${ }^{88}$

Under state corporate law, directors are viewed as trustees and shareholders as beneficiaries of the corporate trust. Directors thus stand in a fiduciary relationship to the shareholders. ${ }^{89}$ Within this framework, it is

83. The seminal case is In re Cady, Roberts \& Co., 40 S.E.C. 907 (1961). The reasoning of this enforcement action was validated by the Second Circuit in SEC v. Texas Gulf Sulphur Co., 401 F.2d 833 (2d Cir. 1968), cert. denied, 394 U.S. 976 (1969).

84. See, e.g., Langevoort, supra note 10 , at $2,6,19$.

85. Id. at 7 .

86. 445 U.S. 222 (1980).

87. 463 U.S. 646 (1983).

88. See Langevoort, supra note 10, at 35; Note, Laventhall v. General Dynamics Corporation: No Recovery for the Plaintiff-Option Holder in a Case of Insider Trading Under Rule 10b-5, $79 \mathrm{Nw}$. U.L. REv. 780, 792 (1984).

89. See, e.g., Litwin v. Allen, 25 N.Y.S.2d 667, 677 (Sup. Ct. 1940); Bodell v. General Gas \& 
axiomatic that shareholders have standing under Rule $10 \mathrm{~b}-5$ to redress insider trading. The term "fiduciary" is not a technical legal definition, however, but a flexible description of any relationship in which one party reposes trust and confidence in another. ${ }^{90}$ The Supreme Court has held, for example, that corporate creditors may also become the beneficiaries of the fiduciary obligation, ${ }^{91}$ and in Chiarella itself, the Court validated the long-standing rule that the fiduciary duty extends to incipient shareholders, ${ }^{92}$ who in theory are not yet the beneficiaries of the corporate trust. ${ }^{23}$

The fiduciary cases-meven those applying the O'Connor exception to the no-standing rule-assume that corporations and insiders are fiduciaries within the meaning of Chiarella only for shareholders, as in state corporate law. This assumption misapprehends the function of the fiduciary principle in modern securities regulation. While the law of corporations uses the term "fiduciary" to regulate matters of internal corporate governance, section 10(b) serves not to establish the rights and duties of security holders within the corporation, but to promote fair and honest securities markets. ${ }^{94}$ In this context, shareholders and option traders have the same functional relationship to the corporation. Both invest capital in the fortunes of the corporation. Both contribute to the firm's ability to attract equity. ${ }^{95}$ Both rely on the corporation to keep them apprised of

Elec. Corp., 15 Del. Ch. 119, 129, 132 A. 442, 446 (Ch. 1926), affd, 15 Del. Ch. 420,140 A. 264 (Sup. C.t. 1927).

90. See, e.g., Roberts v. Sears, Roebuck \& Co., 573 F.2d 976, 983 (7th Cir.), cert. denied, 439 U.S. 860 (1978); United States v. Reed, 601 F. Supp. 685, 704, 712 (S.D.N.Y.), rev'd on other grounds, 773 F.2d 477 (2d Cir. 1985); Coffee, From Tort to Crime: Some Reflections on the Criminalization of Fiduciary Breaches and the Problematic Line Between Law and Ethics, 19 AM. CRIM. L. Rev. 117, 150-51 (1981).

91. Superintendent of Ins. v. Bankers Life \& Casualty Co., 404 U.S. 6, 12 (1971); Pepper v. Litton, 308 U.S. 295, 307 (1939); see also Broad v. Rockwell Int'l Corp., 614 F.2d 418, 430-31 (5th Cir. 1980), cert. denied, 454 U.S. 965 (1981) (control person owed debenture holders fiduciary duty). Courts have also allowed holders of warrants and convertible debentures to sue derivatively on behalf of the corporation, even though that right usually belongs solely to the shareholders. See Hoff v. Sprayregan, 52 F.R.D. 243, 247 (S.D.N.Y. 1971) (convertible debenture holders permitted to sue derivatively under section 10(b) of 1934 Act); Entel v. Guilden, 223 F. Supp. 129, 133 (S.D.N.Y. 1963) (warrant holders permitted to sue derivatively under section 17(e) of Investment Company Act of 1940). While these pre-Chiarella cases are not dispositive, they do suggest that, for the purposes of the federal securities laws, the beneficiaries of the corporate trust include all equity investors in the corporation, even those whose claims are derivative. More compellingly, one court has interpreted Chiarella to allow a class of convertible debenture holders to sue the corporation for nondisclosure of a dividend under Rule $10 \mathrm{~b}-5$ because "directors must act as fiduciaries to all equity participants," including holders of securities containing stock options. Pittsburgh Terminal Corp. v. Baltimore \& O.R.R., 680 F.2d 933, 941 (3d Cir.), cert. denied, 459 U.S. 1056 (1982); see Note, Private Causes of Action for Option Investors Under SEC Rule 10b-5: A Policy, Doctrinal, and Economic Analysis, 100 HaRv. L. Rev. 1959, 1968-69 (1987).

92. That is, to buyers of stock just before the moment of purchase.

93. Chiarella v. United States, 445 U.S. 222, 227 n.8 (1980) (quoting Gratz v. Claughton, 187 F.2d 46, 49 (2d Cir.), cert. denied, 341 U.S. 920 (1951)); see Note, supra note 91, at 1969; see also Kingstone v. Oceanography Dev. Corp., [1978 Transfer Binder] Fed. Sec. L. Rep. (CCH) I 96,387, at 93,348 (S.D.N.Y. Apr. 11, 1978) (insider owes fiduciary duty to incipient bondholders).

94. See, e.g., 15 U.S.C. $\$ 78 b$ (1982); H.R. REP. No. 355, 98th Cong., 2d Sess. 2-3, reprinted in 1984 U.S. CODE ConG. \& ADMIN. NEwS 2274, 2275-76.

95. See supra text accompanying notes 58-62. 
important developments in its affairs. Both are justified in presuming that corporate insiders are not abusing their position by profiting from undisclosed corporate information. ${ }^{96}$ If shareholders in today's anonymous securities marketplace can be said to have "a fiduciary or similar relationship of trust and confidence"97 with corporate insiders, then option traders must be recognized to place equal trust and confidence in the integrity of the people who run the firm in whose performance they invest.

The recent addition of section 20 (d) to the Act $^{88}$ supports the broad reading of the fiduciary principle endorsed here. ${ }^{89}$ In outlawing evasion of fiduciary responsibilities by tipping or trading in options rather than stock, Congress indicates a clear intent to eschew a mechanical approach to insider trading in favor of responsiveness to the real effects of such trading on the fairness and honesty of the securities markets. ${ }^{100}$

The insider owes a fiduciary duty to option traders regardless of whether she trades in stock or in options. The plaintiff is harmed, not by the trading per se, but by the insider's personal use of information that belongs to the corporation. ${ }^{101}$ If disclosure of the inside information would have influenced the stock price, had it been disclosed, then in most cases it would also have influenced the option price. ${ }^{102}$ The lack of potential privity between insiders trading in stock and option traders is irrelevant in an

96. See 3 A. BRomberc \& L. LOWENFELS, supra note 42 , § 7.5(312), at 7:210.

97. See Chiarella, 445 U.S. at 228.

98. 15 U.S.C. $\S 78$ t(d) (Supp. III 1985). This section was one of the amendments to the 1934 Act comprising the Insider Trading Sanctions Act of 1984, Pub. L. No. 98-376, 98 Stat. 1264.

99. Section 20 (d) reads as follows:

Wherever communicating, or purchasing or selling a security while in possession of, material nonpublic information would violate, or result in liability to any purchaser or seller of the security under any provision of this chapter, or any rule or regulation thereunder, such conduct in connection with a purchase or sale of a put, call, straddle, option, or privilege with respect to such security or with respect to a group or index of securities including such security, shall also violate and result in comparable liability to any purchaser or seller of that security under such provision, rule, or regulation.

15 U.S.C. § 78t(d) (Supp. III 1985).

100. See H.R. Rep. No. 355, supra note 94, at 5, reprinted in 1984 U.S. Code Cong. \& ADMIN. News 2278; see also L. Loss, supra note 3, at $732 \mathrm{n} .29$ (section 20 (d) seems to have solved difficulty of finding fiduciary relation to option trader); Wang, A Cause of Action for Option Traders Against Insider Option Traders, 101 HARv. L. REv. 1056 (1988) (option traders can sue insider option traders under section 20(d)). One commentator believes that section 20(d) applies only to SEC enforcement actions. Note, supra note 91 , at 1962 . The text of the amendment, however, indicates otherwise ("liability to any purchaser or seller"). Wang, supra, at 1056-57. Although the portions of the Insider Trading Sanctions Act that amended section 21 ("Investigations and actions") of the 1934 Act were addressed specifically to enforcement proceedings, there is no indication in the legislation or its history that the amendment to section 20 ("Liabilities of controlling persons") was not intended to apply to private actions, as its language suggests.

101. Neither the trading nor the nondisclosure, taken alone, is necessarily illegal. It is trading without disclosure that is prohibited. See, e.g., Shapiro v. Merrill Lynch, Pierce, Fenner \& Smith, 353 F. Supp. 264, 278 (S.D.N.Y. 1972), affd, 495 F.2d 228 (2d Cir. 1974) ("it is not the act of trading which causes plaintiff's injury, it is the act of trading without disclosing material inside information") (emphasis in original); supra note 77.

102. See supra text accompanying notes $79-82$. 
open market trading situation. ${ }^{103}$ To the extent that the $O^{\prime}$ Connor exception reflects the courts' understanding of causation, it is misguided. ${ }^{104}$

The O'Connor court's reliance on a misappropriation theory to support the exception is equally misplaced. Insider trading deprives shareholders of the opportunity to profit from the undisclosed information regardless of whether the insiders trade in stock or in options. Moreover, the Second Gircuit has rejected the use of the misappropriation theory to circumvent the fiduciary duty requirement in a civil case. ${ }^{305}$ In a private $10 \mathrm{~b}-5$ action, the fiduciary duty must run to the plaintiff; the "separate duty" fabricated by the $O^{\prime}$ Connor court runs counter to the clear intent of Chiarella not to make insider trading defendants liable to the entire investing public, but only to those for whom they are fiduciaries. ${ }^{108}$

There is no question that trading on undisclosed inside information by corporations and insiders is illegal. ${ }^{10 z}$ The question is whether all of the

103. The courts have long abandoned the privity requirement in open market trading cases brought under Rule 10b-5. See, e.g., Blue Chip Stamps v. Manor Drug Stores, 412 U.S. 723, 745 (1975).

104. See Note, supra note 88 , at 805-07.

105. In Moss v. Morgan Stanley Inc., 719 F.2d 5 (2d Cir. 1983), cert. denied, 465 U.S. 1025 (1984), a civil action arising from the same events as United States v. Newman, 664 F.2d 12 (2d Cir. 1981), cert. denied, 464 U.S. 863 (1983), on which O'Connor relies, the Second Circuit held that, although Newman breached a fiduciary duty to his co-conspirator's employer by trading on confidential information about impending corporate takeovers, a shareholder in the target company did not have standing to sue him for the breach because he did not owe that duty to the plaintiff. $719 \mathrm{~F} .2 \mathrm{~d}$ at 13 ("Nothing in our opinion in Newman suggests that an employee's duty to 'abstain or disclose' with respect to his employer should be stretched to encompass an employee's 'duty of disclosure' to the general public. . . "There is no "duty in the air" to which any plaintiff can attach his claim." ) (quoting the court below, 553 F. Supp. 1347, 1353 (S.D.N.Y. 1983)); see also 3 A. BROMBERG \& L. LowENFEIS, supra note 42, § 7.5(512), at 7:239-41 (discussing implications of Moss for O'Connor).

In ruling on a motion to dismiss in the ongoing $O^{\prime}$ Connor litigation after Moss was decided, however, the O'Connor court interpreted Moss to apply only where the defendant is not a traditional insider. O'Connor \& Assocs. v. Dean Witter Reynolds, Inc., 600 F. Supp. 702, 703-05 (S.D.N.Y. 1985). But it seems a strained reading of Moss to suppose that where the defendant is a traditional insider, there is a "duty in the air" running to all and sundry under Rule 10b-5.

106. The "broad loophole" analysis of the O'Connor court is also dubious. If insiders trade on undisclosed corporate information in the options market, then shareholders who purchase or sell at the same time are injured by not being able to profit from the undisclosed information held in trust for them by the insiders, See Note, supra note 88, at 806 n.140; supra note 77 . In such a situation, shareholders should have standing to redress their injury. The Insider Trading Sanctions Act of 1984, although ambiguously worded, may support this result. See 15 U.S.C. § 78t(d) (Supp. III 1985).

Curiously enough, the O'Cornor approach to the fiduciary duty problem is endorsed by several commentators. See Note, supra note 91, at 1971; Note, supra note 88, at 794-98, 807-08 (fiduciary duty requirement should be used only to limit defendant class, as in $0^{\prime}$ Connor, not plaintiff class, as in Laventhall). In their zeal to advance their argument, these writers overlook the logical and doctrinal difficulties with $O^{\prime}$ Connor. In advocating the use of the fiduciary duty requirement solely as a limit on the defendant class, they lose sight of the common-law origins of insider trading as a tort, to which the Supreme Court clearly harks back in Chiarella. See 445 U.S. at 227-28 \& n.9 (citing Restatement (SECOND) of TORTS $\$ 551(2)$ (a) (1976)). The requirement of a duty in tort law serves to limit both the defendant and the plaintiff classes: The defendant must have had a duty to the plaintiff to perform or refrain from the act in question. See, e.g., RESTATEMENT (SECOND) OF TORTS $\S 4$ (1965). While the Court does not explicitly adopt this analysis in Chiarella because the case did not involve a private plaintiff, its emphasis on the common-law tort origins of the cause of action indicate that it intends the fiduciary principle to serve this dual purpose under Rule $10 \mathrm{~b}-5$.

107. Unlike the misappropriation cases, in which the court tries to define new categories of people as insiders, the option trader cases involve traditional insiders who can unquestionably be prosecuted 
foreseeable victims of the trading, or just some of them, can obtain redress in court. ${ }^{108}$ Like shareholders, option traders invest in the fortunes of the corporation with the expectation that the corporate entity and its insiders will not convert inside information to their own use at investors' expense. Like shareholders, they should have standing to recover the unjustly earned profits of insiders who betray their trust. ${ }^{109}$

\section{B. Misrepresentation and the Fiduciary Principle}

Unlike the judicially created cause of action for insider trading, liability for misrepresentation arises from the text of Rule 10b-5, which makes it "unlawful for any person. . . [t]o make any untrue statement of a material fact or to omit to state a material fact necessary in order to make the statements made . . . not misleading . . .."110 The Rule explicitly addresses not nondisclosure, as in the insider trading cases, but misleading disclosure. ${ }^{111}$ By its own terms, the Rule applies to all disclosures; it is not limited to disclosures to particular parties or within particular relationships. ${ }^{112}$ Unlike insider trading claims, Rule $10 \mathrm{~b}-5$ claims brought on a misrepresentation theory rest on a statutory duty to the entire investing public to disclose truthfully and openly. ${ }^{113}$

Except in the fiduciary option traders cases, no court addressing a misrepresentation claim has attempted to limit this statutory duty to disclosures between fiduciaries. ${ }^{114}$ To the contrary, the cases make quite clear that the existence of a duty to disclose prior to the offending disclosure is irrelevant to liability for making a false or misleadingly incomplete statement; the duty to disclose truthfully arises when the defendant undertakes to speak. ${ }^{115}$ It is commonplace, for example, for classes of bondholders and debentureholders, for whom corporations are not traditionally considered fiduciaries, ${ }^{116}$ to sue issuers under Rule $10 \mathrm{~b}-5 .{ }^{117}$

\footnotetext{
criminally for insider trading.

108. See O'Connor, 529 F. Supp. at 1187-88.

109. See Note, supra note 88 , at $781 \mathrm{n} .10$ (whatever goals of deterrence or compensation are served by private actions under Rule 10b-5, they apply to suits brought by shareholders and by option holders alike).

110. 17 C.F.R. $§ 240.10 \mathrm{~b}-5$ (1987).

111. See supra notes $12-13$.

112. See, e.g., L. Loss, supra note 3 , at 723.

113. The Supreme Court recently described this duty as "the ever-present duty not to mislead" imposed even on "those under no duty to disclose." Basic, Inc., v. Levinson, [Current Binder] Fed. Sec. L. Rep. (CCH) I 93,645, at 97,948 n.18 (U.S. Mar. 7, 1988).

114. See Deutschman v. Beneficial Corp., [Current Binder] Fed. Sec. L. Rep. (CCH) I 93,655, at 98,012 (3d Cir. Mar. 7, 1988) (no federal appeals court has imposed transactional nexus requirement in representation cases).

115. See, e.g., Deutschman, II 93,655, at 98,011; Greenfield v. Heublein, Inc., 742 F.2d 751, 756 (3d Cir. 1984), cert. denied, 469 L.S. 1215 (1985); Panter v. Marshall Field \& Co., 646 F.2d 271, 292 (7th Cir.), cert. denied, 454 U.S. 1092 (1981).

116. See, e.g., Langevoort, supra note 10, at 40 . But see Superintendent of Ins. v. Bankers Life \& Casualty Co., 404 U.S. 6, 12 (1971) (fiduciary obligation designed for protection of entire community of interests in corporation), quoting Pepper v. Litton, 308 U.S. 295, 307 (1939) (in event of bankruptcy, fiduciary obligation enforceable by trustee of creditors).
} 
The fiduciary courts' extension of a fiduciary duty requirement to misrepresentation cases rests on an extremely strained reading of Chiarella. In that case, the Court draws a clear distinction between affirmative misrepresentation and nondisclosure before trading. ${ }^{118}$ The holding is explicitly limited to cases of nondisclosure. ${ }^{119}$ Except in the fiduciary option trader cases, no court has held that Chiarella's fiduciary limitation applies to misrepresentation claims. ${ }^{120}$

The notion that $10 \mathrm{~b}-5$ defendants in misrepresentation cases are liable only to plaintiffs to whom they owe a pre-existing duty of disclosure is also belied by the Supreme Court's recent acceptance of the fraud-on-themarket theory. ${ }^{121} \mathrm{By}$ allowing plaintiffs to prove reliance on the basis of their general belief in the integrity of the market, rather than on particular disclosures directed at them, the fraud-on-the-market theory demonstrates that Rule 10b-5's requirement of truthful disclosure extends to all statements materially affecting the value of securities, regardless of the relationship between the parties. ${ }^{122}$

The fiduciary courts' requirement of a fiduciary duty as a prerequisite for liability in misrepresentation cases under Rule $10 \mathrm{~b}-5$ is a radical and unjustified departure from established case law. There is no reason of policy or doctrine to deny option traders standing to bring misrepresentation claims.

\section{CONCLUSION}

The approach to the standing of option traders under Rule 10b-5 proposed in this Note is an attempt in just one area to meet the broader challenge to federal securities regulation posed by the changing character

117. See, e.g., Harris v. Union Elec. Co., 787 F.2d 355 (8th Cir.), cert. denied, 107 S. Ct. 94 (1986) (class of bondholders); Broad v. Rockwell Int'l Corp., 614 F.2d 418 (5th Cir. 1980), cert. denied, 454 U.S. 965 (1981) (class of debenturenolders).

118. Chiarella v. United States, 445 U.S. 222, 227-28 (1980); see Deustchman v. Beneficial Corp., [Current Binder] Fed. Sec. L. Rep. (CCH) If 93,655, at 98,011 (3d Cir. Mar. 7, 1988) ("Nothing in [Chiarella or Dirks] . . . can be construed to require the existence of a fiduciary relationship between [a] section 10(b) defendant and the victim of that defendant's misrepresentation.").

119. Chiarella, 445 U.S. at 235.

120. See Deutschman, II 93,655, at 98,012; Rowe v. Maremont Corp., 650 F. Supp. 1091, 1104-05 (N.D. Ill. 1986); Rose v. Arkansas Valley Envtl. \& Util. Auth., 562 F. Supp. 1180, 1206-08 (W.D. Mo. 1983).

121. Basic, Inc., v. Levinson, [Current Binder] Fed. Sec. L. Rep. (CCH) II 93,645, at 97,949-52 (U.S. Mar. 7, 1988). For discussion of the economic principles underlying the theory, see In re LTV Sec. Litig., 88 F.R.D. 134, 142-45 (N.D. Tex. 1980); Fischel, Use of Modern Finance Theory in Securities Fraud Cases Involving Actively Traded Securities, 38 Bus. LAw. 1, 3-5, 9-11 (1982); Note, The Fraud-on-the-Market Theory, 95 HARv. L. REv. 1143, 1153-56 (1982). The fraud-onthe-market theory makes it immensely easier for plaintiffs to certify a class of investors and to prove their collective reliance.

122. The fraud-on-the-market theory is discussed in Note, supra note 91 , at 1976-77, insofar as it heips option trader plaintiffs demonstrate a causal connection between the misrepresentation and their injury. The theory undoubtedly facilitates proof of reliance and causation for both stockholder and option trader plaintiffs. The more important implication of the theory's acceptance, however, is the broad vision of full and fair disclosure to the investing public that informs it. 
of today's securities markets. As ever-more-exotic financial instruments are introduced both on the exchanges and over the counter, the courts will have to revise their interpretation of the federal securities laws. Traditional equitable prejudices against leveraged securities make little sense in light of modern economic understanding of the benefits of efficient risk transfer conferred by derivative securities. Characterizations of market relationships borrowed from the state law of corporations are no longer adequate to address the more complex relationships created by the new securities trading. These formalistic categories, developed in an age of conventional corporate-issued securities and privity between purchaser and seller, are useless in contemporary securities regulation unless applied with an understanding of the structural relationships of market participants and the economic interaction among markets. If the securities acts are to remain a dynamic force in creating efficient capital markets, their interpretation cannot be static. Unless Congress acts, it is up to the courts to adapt these old statutes to the demands of a new age. 
